\title{
Deladenus siricidicola, BEDDING (NEOTYLENCHIDAE) PARASITISM EVALUATION IN ADULT Sirex noctilio, FABRICIUS, 1793 (HYMENOPTERA: SIRICIDAE) ${ }^{1}$
}

\author{
FENILI, R., ${ }^{2}$ MENDES, C. J., ${ }^{3}$ MIQUELLUTI, D. J., ${ }^{4}$ MARIANO-DA-SILVA, S., ${ }^{5}$ \\ XAVIER, Y., ${ }^{5}$ RIBAS, H. S. ${ }^{5}$ and FURLAN, G. ${ }^{5}$ \\ ${ }^{1}$ Convênio Associação Catarinense de Reflorestadores, Centro Agroveterinário, Universidade do Estado de Santa \\ Catarina, CAV/UDESC \\ ${ }^{2}$ Centro Agroveterinário, CAV/UDESC, Av. Luiz de Camões, 2.090, CEP 88520-000, Lages, SC, Brazil \\ ${ }^{3} \mathrm{PCC}$, Papel e Celulose Catarinense \\ ${ }^{4}$ Estatística e Experimentação, Centro Agroveterinário, CAV/UDESC, Av. Luiz de Camões, 2.090, CEP 88520-000, \\ Lages, SC, Brazil \\ ${ }^{5} \mathrm{CAV} / \mathrm{UDESC}$ \\ Correspondence to: Samuel Mariano da Silva, Laboratório de Bioquímica, Departamento de Ciências Biológicas, \\ Escola Superior de Agricultura “Luiz de Queiroz", USP, Avenida Pádua Dias, 11, C.P. 09, CEP 13418-900, \\ Piracicaba, SP, Brazil, e-mail: smgsilva@carpa.ciagri.usp.br \\ Received November 22, 1999 - Accepted January 5, 2000 - Distributed November 30, 2000
}

\begin{abstract}
This work aimed to evaluate the Deladenus siricidicola, Bedding (Neotylenchidae) parasitism in adults Sirex noctilio, Fabricius, 1793 (Hymenoptera: Siricidae). Timber was sampled by cutting out pieces of $0.80 \mathrm{~m}$ in length in Sirex noctilio attacked and Deladenus siricidicola inoculated Pinus taeda. Longs were $15-20 \mathrm{~cm}$ in diameter, according to the tree age. Samples were packed in gauze-cages, for daily observations, till S. noctilio adults emergence. The emerged insects were transported, in plastic containers to the laboratory, where they were sectioned and dissected under stereoscopic microscopy to observ the nematode occurrence. From the initially proposed ten units, nine of them were evaluated in a total of 1,810 emerged adult insects, being 1,441 males and 369 females. Nematode parasitism was shown in 267 males and 74 females, in a total of 341 infected insects $(18.84 \%)$.
\end{abstract}

Key words: Sirex noctilio, Deladenus siricidicola, parasitism, biological control.

\section{RESUMO}

Avaliação do parasitismo de Deladenus siricidicola, Bedding (Neotylenchidae) em Sirex noctilio, Fabricius, 1793 (Hymenoptera: Siricidae) adultos

O objetivo do presente trabalho foi avaliar o parasitismo do nematóide Deladenus siricidicola, Bedding (Neotylenchidae) em adultos de Sirex noctilio, Fabricius, 1793 (Hymenoptera: Siricidae). Foram utilizados toretes de 0,80 cm de comprimento, retirados do terço médio de árvores de Pinus taeda atacadas por Sirex noctilio e inoculadas com Deladenus siricidicola. Os toretes possuíam diâmetro entre 15$20 \mathrm{~cm}$, de acordo com a idade das árvores. As amostras foram acondicionadas em gaiolas ou tonéis vedados com tela de nylon e seguros por cintas de borracha, permanecendo em observação diária até a emergência dos insetos adultos. Os insetos foram trasportados em recipientes plásticos para o laboratório, onde foram seccionados e dissecados sob microscópio estereoscópico, para a verificação da ocorrência ou não do nematóide. Foram avaliadas nove das dez unidades inicialmente propostas. Nestas, foram analisados 1.810 insetos adultos, sendo 1.441 machos e 369 fêmeas. O parasitismo pelo nematóide foi verificado em 267 machos e 74 fêmeas, em um total de 341 insetos parasitados, com uma porcentagem de parasitismo de $18,84 \%$.

Palavras-chave: Sirex noctilio, Deladenus siricidicola, parasitismo, controle biológico. 


\section{INTRODUCTION}

The woodwasp Sirex noctilio, Fabricius, 1793 (Hymenoptera: Siricidae) is native insect in southern Europe, the Near East and North Africa, where it attacks and breeds in the holes of weakened and dying pines. It is not considered as pest in its native habitat. During the early 1900's, S. noctilio was detected in New Zealand in imported pine logs from Europe (Cielsa, 1992).

By the end of the Second World War, $S$. noctilio was causing an extensive mortality in New Zealand exotic conifer plantations. Infestations were firstly detected in Tasmania in 1952 and in the Australian Mainland in 1961 (Cielsa, 1992; Eldridge \& Taylor, 1989; Taylor, 1981; Zondag \& Nuttall, 1977).

More recently, S. noctilio was found in South America. Infestations are now known to occur in Argentina, Uruguay, Chile and Brazil, where Pinus taeda, a pine tree native to the Southeastern United States, is the principle species affected (Cielsa, 1992). Infestations were detected in Uruguay in 1980. By 1990, plantations of P. taeda, P. elliottii and $P$. pinaster throughout the country had suffered damage (Rebuffo, 1990). In Brazil, its presence was detected in 1988, attacking $P$. taeda plantations, inicially in Rio Grande do Sul (Iede et al., 1988) and later in Santa Catarina (Mendes, 1992).

Sirex wasp attack causes stress and it kills trees by the injection of phytotoxic mucus and spores of the symbiotic pathogenic basidiomycete Amylostereum areolatum (Fries) Boidin (commonly known as the sirex fungus) into outer sapwood during ovoposition. This pathogen desiccates the wood, causes white rot, and it is also a source of nutrients for the wasp larvae. Additional degradation in the wood occurs by the larvae tunneling activity and by an attack of secondary decaying fungi which enter via flight holes. In a year the wood will loose its commercial value (Diodato, 1995; Kille et al., 1974; Neumann et al., 1987).

Its control began in Australia when the nematode Deladenus siricidicola, Bedding (Neotylenchidae) and other parasites were introduced (Nuttall, 1980a). D. siricidicola nematode, according to the National Sirex Control Strategy in Australia (NSCS, 1991), is known to be the most important parasite for its biological characteristics and by laboratory multiplication facility. The nematode is artificially inoculated in the cuter sapwood of sirex-infested trap trees and significantly suppresses the fecundity of females without impairing their general sexual vigor and competitiveness. The parasitoid can also kill early wasp larvae (Neumann et al., 1987; Nuttall, 1980b).

D. siricidicola use and its field artificial inoculation, depends on its parasitism degree (NSCS, 1991) emphasized by the key factors: freeing effectiveness evaluation to its establishment; specific village evaluation to dispersion determination; recommendation to evaluation in adult insects, males and females. The Fundo Nacional de Controle da Vespa-da-madeira (Funcema, 1993) recommendation in Brazil is that in villages where the parasitism level detected is higher than $30 \%$, artificial inoculations should not be made in the following years, and maintaining the forest monitoring.

This work aimed to evaluate the $D$. siricidicola parasitism in adult $S$. noctilio.

\section{MATERIAL AND METHODS}

Timber was sampled by cutting out pieces with $0.80 \mathrm{~m}$ length, in the tree medium third part (Haugen, 1991), in $S$. noctilio attacked and $D$. siricidicola inoculated trees. Logs were $15-20 \mathrm{~cm}$ in diameter, according to the tree age.

Logs were collected in ten geographic units in Santa Catarina State, Brazil, shown in Table 1. In each unit it was sampled four reforestation, removed four trees per reforestation and three logs per tree, to have $480 \operatorname{logs}$ in total. Material was sampled during November of 1995 and February of 1996.

Samples were taken to the Centro de Ciências Agroveterinárias - CAV/UDESC, where some of them were stored in $1.00 \times 1.20 \mathrm{~m}$ gauze cages and the others in $200 \mathrm{~L}$ casks covered with nylon gauzes fixed by elastic rubber girdles.

Daily observation were carried out till adults emergency. The insects were transported in plastic containers to the laboratory, where they were sectioned and dissected under stereoscopic microscopy (40x magnification) to observe nematode occurrence, according to NSCS (1991) and Mendes (1992) methodology. A parasitism value of $30 \%$ was used as an efficiency referential (Funcema, 1993). 
TABLE 1

Geographic units of material collect.

\begin{tabular}{|l|l|}
\hline Unit 01 & Irani region municipalities \\
\hline Unit 02 & Campos Novos region municipalities \\
\hline Unit 03 & Campo Belo do Sul, Anita Garibaldi and Lages (Paequerê and BR 116 region) \\
\hline Unit 04 & Correia Pinto, São José do Cerrito and Lages (sede region) region municipalities \\
\hline Unit 05 & São Joaquim and Bom Jardim da Serra municipalities \\
\hline Unit 06 & Bom Retiro (Santa Clara region) and Urubici municipalities \\
\hline Unit 07 & Alfredo Wagner, Imbuia, Leoberto Leal and Bom Retiro (Barbaquá region) municipalities \\
\hline Unit 08 & Otacílio Costa (Fundo do Campo region) and Lages (Bocaina) municipalities \\
\hline Unit 09 & Otacílio Costa and Ponte Alta municipalities \\
\hline Unit 10 & Santa Cecília region municipalities \\
\hline
\end{tabular}

Results for proportions were statistically analyzed by the $\mathrm{Z}$-test, comparing the region total parasitism percentage per sex to the $30 \%$ standard value. Variance analysis was used to analyze the variable infestation for each reforestation region and insect sex following a casual ship delineation in hierarchic model, witch 12 repetitions. Treatment variation stabilization was made according the square root arcsin transformation (Bishop, 1966; Snedecor \& Cochran, 1967).

\section{RESULTS AND DISCUSSION}

From the initially proposed ten units, nine of them were evaluated in a total of 1,810 emerged adult insects, being 1,441 males and 369 females. Nematode parasitism was shown in 267 males and 74 females, in a total of 341 infected insects $(18,84 \%)$.

The total parasitism (males and females) and percentage per unit are shown in Table 2.

The low emergence number shown for each unit might be due to the sampling period and the transference to CAV, when many of adult insects were already emerged.

The results obtained in $\mathrm{U} 2, \mathrm{U} 4, \mathrm{U} 8$ and $\mathrm{U} 10$ should be carefully considered due to the low number of observed insects. The resultant rates in U3, U5, U6, U7 and U9 were satisfactory, considering parasitism percentage rates observed in other regions (Mendes, 1992). According to the literature, the nematode applications should be con- tinued, since the parasitism rate was lower then $30 \%$.

After result statistics analysis, was confirmed that in $\mathrm{U} 2, \mathrm{U} 4, \mathrm{U} 6$ and $\mathrm{U} 10$ the parasitism rate was higher then $30 \%(p>0.05)$ for both sex. In U3, U5 e U9 it was low then $30 \%$ ( $p>0.05$ ) for both sex. In U7 and U8 it was higher then $30 \%$ $(\mathrm{p}>0.05)$ for females and lower then $30 \%$ ( $p>$ $0.05)$ for males.

The observed variation might be the result from stored nematode viability from its production until its field inoculation, the gelatin preparation (used as inoculation vehicle), application mode (application hammer), nematode migration ability in tree, the infection losing of the nematode strain, and climate conditions, as temperature during inoculation.

The averages of nematode parasitism percentages, in $S$. noctilio males and females, in different units and reforestation places, considering all the analyzed repetitions (with or without adult emergence) are shown in Table 3.

The results showed no differences among reforestation averages in U3 and U5. The reforestation with greater parasitism level were P1, P2 and P3. In U6, P3 it was shown the higher parasitism rates. In U7 were $\mathrm{P} 2$ and $\mathrm{P} 4$, whereas in $\mathrm{U} 9$ the greater parasitism rate was P1. Analysis of region averages showed higher parasitism rate in U5, U6 and U7, whereas smaller rates were observed in U3 and U9. Perhaps the same factors above listed influenced this variation. 
TABLE 2

Collection realized in November-February (emerged adults and parasitism percentage).

\begin{tabular}{|c|c|c|c|c|c|c|c|c|}
\hline Unity & Adult & M & F & \multicolumn{2}{|c|}{ Parasitism } & \multicolumn{2}{|c|}{ Total } \\
\hline & Total & & & M & F & M & F & Parasitism $(\%)$ \\
\hline U1 & 1 & 1 & 0 & 0 & 0 & 0 & 0 & 0 \\
\hline U2 & 10 & 5 & 5 & 2 & 2 & 40.00 & 40.00 & 40.00 \\
\hline U3 & 139 & 118 & 21 & 11 & 0 & 09.32 & 0 & 7.91 \\
\hline U4 & 34 & 21 & 13 & 6 & 2 & 28.57 & 15.38 & 23.53 \\
\hline U5 & 1,103 & 942 & 161 & 163 & 30 & 17.30 & 18.43 & 17.49 \\
\hline U6 & 159 & 121 & 38 & 45 & 10 & 37.19 & 16.31 & 34.60 \\
\hline U7 & 212 & 130 & 82 & 25 & 20 & 19.23 & 24.39 & 21.23 \\
\hline U8 & 21 & 16 & 5 & 0 & 4 & 0 & 80.00 & 19.05 \\
\hline U9 & 112 & 74 & 38 & 11 & 5 & 14.86 & 13.15 & 14.28 \\
\hline U10 & 20 & 14 & 6 & 4 & 1 & 28.57 & 16.66 & 25.00 \\
\hline
\end{tabular}

$\mathrm{M}=$ males; $\mathrm{F}=$ females.

TABLE 3

Averages of nematode parasitism percentage in $S$. noctilio in units and reforestation places.

\begin{tabular}{|c|c|c|c|c|c|}
\hline & U3 & U5 & U6 & U7 & U9 \\
\hline P1 & $4.98 \mathrm{a}$ & $25.23 \mathrm{a}$ & $8.44 \mathrm{~b}$ & $3.04 \mathrm{~b}$ & $16.68 \mathrm{a}$ \\
\hline P2 & $5.87 \mathrm{a}$ & $4.60 \mathrm{~b}$ & $1.00 \mathrm{~b}$ & $22.64 \mathrm{a}$ & $1.00 \mathrm{~b}$ \\
\hline P3 & $1.00 \mathrm{a}$ & $14.03 \mathrm{ab}$ & $22.28 \mathrm{a}$ & $1.00 \mathrm{~b}$ & - \\
\hline P4 & - & $16.84 \mathrm{ab}$ & $5.26 \mathrm{~b}$ & $16.31 \mathrm{a}$ & - \\
\hline Means & $3.95 \mathrm{C}$ & $15.18 \mathrm{~A}$ & $9.24 \mathrm{AB}$ & $10.75 \mathrm{AB}$ & $8.84 \mathrm{BC}$ \\
\hline Coefficient of variation & & & $42.89 \%$ \\
\hline
\end{tabular}

$\mathrm{U}=$ unit; $\mathrm{P}=$ reforestation place.

Sampling period should be during August and September, for a standard emerged adult collection, avoiding the samples where a great number of adult emergence occurred. In units with low parasitism, it is suggested to review the operation proceedings, meaning the identification of causes and the collection training.

\section{REFERENCES}

BISHOP, O. N., 1966, Statistics for biology. Boston, Houghton Mifflin Company, 182p.

CIELSA, W. M., 1992, Recent introductions of forest insects and their effects: a worldwide overview. In: Conferência Regional da Vespa-da-Madeira Sirex noctilio na América do Sul, 1, Vol. I, Florianópolis, 1992. Anais. EMBRAPAICNPFlorestas\FAO-ONUIUSFA-Forest Service/FUNCEMA, Florianópolis, pp. 09-21.
DIODATO, M. A., 1995, Controle da vespa-da-madeira. Ciência Hoje, 19(113): 21-24.

ELDRIDGE, R. H. \& TAYLOR, E. E., 1989, Sirex woodwasp: a pest of pine in N.S.W. Forest Protection Series n. 1. Wood Technology and forest Research Division, Forest Commission of New South Wales, Beecoft, Australia, 5p.

FUNCEMA - Fundo Nacional de combate à vespa-damadeira, 1993, Reunião Funcema, Comissão Técnica, Avaliação do Programa Nacional e Novos Projetos. Lages, SC, 4p.

HAUGEN, D. A., 1991, Woodship sampling for the nematode Deladenus siricidicola and the relationship with the percentage or Sirex noctilio infected. Australian Forest Research, 54(1/2): 03-08.

IEDE, E. T., PENTEADO, S. R. C. \& BISOL, J. C., 1988, Primeiro registro de ataque de Sirex noctilio em Pinus taeda no Brasil. Circular Técnica 20. EMBRAPA-CNPF, Colombo, PR, 12p. 
KILLE, G. A., BOWLING, P. J., DOLEZAL, J. E. \& BIRD, T., 1974, The reaction of Pinus radiata twinges to the mucous of Sirex noctilio in relation to Sirex attack. Australian Forest Research, 6(3): 25-34.

MENDES, C. J., 1992, Manual de controle da vespa-damadeira. Associação Catarinense dos Reflorestadores, Florianópolis, SC, 23p.

NSCS - National Sirex Control Strategy, 1991, Operations Worksheets Committee, n. 6. Worksheet, NSCS, 25p.

NEUMANN, F. G., MOREY, J. L. \& McKIMM, R. J., 1987, The Sirex wasp in Victoria. Bulletin 29. Department of Conservation Forests and Lands, Melbourne, Australia, $41 \mathrm{p}$.

NUTTALL, M. J., 1980a, Insects parasites of Sirex (Hymenoptera: Ichneumonidae, Ibaliidae and Orussidae). Forest and timber insects in New Zealand, n. 47. Forest Research Institute, Rotorua, New Zealand, 11p.

NUTTALL, M. J., 1980b, Deladenus siricidicola, Bedding (Nematoda: Neotylenchidae) nematode parasite of Sirex. Forest and timber insects in New Zealand, n. 48. Forest Research Institute, Rotorua, New Zealand, 9p.
REBUFFO, S., 1990, La aviespa de la madera Sirix noctilio en el Uruguay. Ministerio de Ganaderia, Agricultura y Pesca, Dirección Florestal, República Oriental del Uruguay, $17 \mathrm{p}$.

SNEDECOR, G. W. \& COCHRAN, W. G., 1967, Statistical methods, 6⿳一巛工 ed., The Iowa State University Press, Iowa, USA, 593p.

TAYLOR, K. L., 1981, The Sirex woodwasp: ecology in control of an introduced forest insect. In: R. Kitching, \& R. Jones (eds.), The ecological of pests some Australian cases histories. Melbourne, CSIRO. Chapter 12, pp. 231-248.

ZONDAG, R. \& NUTTALL, M. J., 1977, Sirex noctilio, Fabricius (Hymenoptera, Siricidae). Forest and timber insects in New Zealand, n. 20. Forest Research Institute, Rotorua, New Zealand, 7p. 